\title{
Maria Libiszowska-Żółtkowska, Homo religiosus. Szkice socjologii religii, Zakład Wydawniczy NOMOS, Kraków 2021, sS. 295
}

W swej wieloletniej aktywności naukowej prof. Maria Libiszowska-Żółtkowska w umiejętny sposób, naznaczony wyobraźnią socjologiczną, kompetencją badawczą i wrażliwością etyczną, podejmowała aktualne i ważne problemy należące do trzech subdyscyplin socjologicznych: socjologii religii, socjologii nowych ruchów religijnych oraz socjologii medycyny. Jest ona autorką lub współautorką kilkunastu książek, ponad trzystu artykułów i rozdziałów w pracach zbiorowych oraz wielu publikacji o charakterze popularnonaukowym. Wśród książek, które weszły do kanonu polskiej socjologii, należy wymienić: „Postawy inteligencji wobec religii” (Warszawa 1991); „Szkice socjologii medycyny” (Lublin 1998); „Wiara uczonych. Esej socjologiczny mocno osadzony w empirii” (Kraków 2000); „Nowe ruchy religijne w zwierciadle socjologii” (Warszawa 2001); „Konwertyci nowych ruchów religijnych” (Lublin 2003); „Leksykon socjologii religii. Zjawiska - badania - teorie” (Warszawa 2004); „Tożsamości religijne w społeczeństwie polskim. Socjologiczne studium przypadków” (Warszawa 2009); „Religijność i duchowość: dawne i nowe formy” (Kraków 2010).

1 Janusz Mariański, Instytut Nauk Socjologicznych, Katolicki Uniwersytet Lubelski Jana Pawła II, Polska, e-mail: januszm@kul.lublin.pl, ORCID ID: https://orcid.org/0000-00020620-8000. 
Powyższe publikacje cechuje wysoki poziom merytoryczny i bardzo dobre osadzenie w literaturze socjologicznej polskiej i zagranicznej. Podejmowane przez Libiszowską-Żółtkowską problemy socjologiczne odnoszą się do najważniejszych kwestii z zakresu socjologii religii, a zwłaszcza socjologii nowych ruchów religijnych. Bada ona religię jako zjawisko społeczne wielowymiarowo. W perspektywie ogólnej określa ją wielkością deklarowanego globalnego wskaźnika wiary i skalą społecznych odniesień do autorytetu Kościoła. Na poziomie jednostkowym i grupowym religia jest definiowana w kontekście wartości warunkujących jakość życia codziennego. Religia nie tylko objaśnia świat, ale również przyczynia się do tworzenia ładu społecznego, współtworzy syntezę wartości i norm moralnych oraz wzory sensownego życia.

Z socjologicznego punktu widzenia ,,religia to wynikający z dualistycznego rozróżnienia na rzeczywistość empiryczną i transcendentną system wierzeń, który choć sam nie poddaje się racjonalnej weryfikacji, to wyjaśnia w sposób możliwy do przyjęcia - to wszystko, co dla zmysłów nie pojęte i co w inny sposób wytłumaczyć się nie da; odpowiadające tym wierzeniom symbole i formy zachowań kultowych; zbiór wartości i norm moralnych odwołujących się do autorytetu Boga i Kościoła, a określający wzór osobowy człowieka religijnego oraz jednocząca wyznawców we wspólnotę organizacja kościelna” (Libiszowska-Żółtkowska, 1998, s. 43). Strukturalnymi składnikami definicji religii są: doktryna religijna (system wierzeń, zbiór prawd wiary), kult (zachowania, praktyki religijne), doktryna etyczna (zbiór wartości i norm moralnych) oraz organizacja (jako urząd i jako wspólnota wiernych) (Libiszowska-Żółtkowska, 2000, s. 9, 17).

W wielu tekstach prof. Maria Libiszowska-Żółtkowska podejmuje w sposób pogłębiony i refleksyjny, a przede wszystkim osadzony w podstawowej i najnowszej literaturze przedmiotu, społecznie ważki problem religijności współczesnych Polaków. Dyskurs socjologiczny prowadzony jest z jednej strony z punktu widzenia paradygmatu sekularyzacyjnego, który zdaniem wielu socjologów wyznacza miejsce religii we współczesnym świecie (zwłaszcza w Europie Zachodniej), z drugiej strony z perspektywy teorii prywatyzacji (indywidualizacji) wiary i selektywności wartości i norm (teorie pluralizmu) oraz teorii desekularyzacji (różne formy ożywienia religijnego). Socjologiczne badania religijności katolickiej dotyczą parametrów: wiary, praktyk oraz moralności określanej jako parametr konsekwencji, a także postaw wobec Kościoła jako instytucji religijnej i społecznej.

Niniejsza publikacja, nosząca tytuł „Homo religiosus. Szkice socjologii religii”, stanowi zwarty zbiór wybranych tekstów autorki z ostatnich trzydziestu lat. Zdecydowaną większość tych tekstów czytałem już wcześniej, tylko kilka z nich przeczytałem po raz pierwszy. Wspólnie z Panią Profesor współredagowałem 
„Leksykon socjologii religii. Zjawiska - badania - teorie” (Warszawa 2004). Zamieszczone w tym zbiorze artykuły ukazują wielowymiarowość i złożoność zjawiska, jakim jest religia. Wszystkie teksty oceniam bardzo wysoko. Szkoda tylko, że niektóre ważne opracowania znalazły się poza tym wyborem tekstów z bogatej twórczości prof. Marii Libiszowskiej-Żółtkowskiej (np. „Religia jako determinanta tożsamości studentów i konwertytów”; „Sekty jako zagrożenie cywilizacyjne”; „Kultura moralna konwertytów nowych ruchów religijnych”; „Postawy inteligencji wobec religii - dziesięć lat później”).

Zawarte w publikacji teksty, zgrupowane w trzech częściach, po sześć artykułów w każdej z nich, choć odnoszą się do wielu pól badawczych i interpretacji związanych z problematyką szeroko pojętej religii, Kościoła i nowych ruchów religijnych, to stanowią wspólną całość ze względu na spinającą ją klamrę podejścia socjologicznego, neutralnego pod względem aksjologicznym i światopoglądowym opartych na obiektywnych analizach socjologicznych. Nikt, kto zajmuje się badaniem kondycji religijnej i moralnej społeczeństwa polskiego, nie może pominąć tego opracowania, które z pewnością wejdzie do kanonu obowiązkowych lektur dla socjologów religii w naszym kraju.

W pierwszej części noszącej tytuł „Kościół katolicki w Polsce” autorka podejmuje następujące problemy: Państwo a Kościół. Zmienność wzajemnych relacji w dziejach chrześcijańskiej Europy; Kościół katolicki w przestrzeni publicznej i prywatnej w Polsce Ludowej i w III Rzeczpospolitej; Kościół w Polsce z perspektywy rynkowej teorii religii; Sekularyzacja - wróg czy sprzymierzeniec Kościoła katolickiego w Polsce?; Świeccy apostaci o duchowieństwie oraz o funkcjach i dysfunkcjach Kościoła katolickiego - wyniki badań socjologicznych; Resakralizacja w ponowoczesnej scenerii. Nowe odsłony religii i duchowości.

W swoich diagnozach i interpretacjach współczesnego polskiego katolicyzmu Libiszowska-Żółtkowska jawi się jako osoba kompetentna, jako niekwestionowany znawca problematyki społeczno-religijnej, zarówno od strony teorii, jak i empirii. W latach dziewięćdziesiątych ubiegłego wieku doszła do wypracowania kilku ważnych syntez dotyczących religijności społeczeństwa polskiego i sformułowała wiele ważnych i nośnych hipotez teoretycznych. Jest bardzo dobrze zorientowana w najnowszych dyskusjach teoretycznych i metodologicznych z zakresu socjologii religii, zwłaszcza zaś socjologii nowych ruchów religijnych.

Analizy religijności odnoszące się do badania stopnia koherencji między sferą deklaracji a rzeczywistymi postawami i zachowaniami ujawniają zakres konsekwencji wiary i określają typ orientacji religijnej, bądź w odniesieniu do modelu kościelnego (ujęcie normatywne), bądź modelu sensotwórczego znaczenia wiary w indywidualnym świecie wartości, norm i motywacji (ujęcie aksjologiczne). Te 
dwa aspekty: deklaratywny i aplikatywny w sferze przekonań, praktyk religijnych i wyborów moralnych charakteryzuje jej metodologię badań nad religijnością, zarówno w analizach dotyczących płaszczyzny ogólnopolskiej, jak i w odniesieniu do wybranych środowisk społecznych (np. inteligencja, studenci). Zakłada ona słusznie, że o autentycznej religijności nie decydują odświętne deklaracje ani społecznie wiodąca rola Kościoła w społeczeństwie, lecz jego oddziaływanie na moralność jednostek, grup społecznych i całego społeczeństwa. ,Etyka sytuacyjna i relatywizm moralny w kontekście tłumnie wypełnionych świątyń wskazują na istnienie dysonansu między realizowaną sferą powinności kultowych a zaniedbywaną sferą powinności moralnych” (Libiszowska-Żółtkowska, 1991, s. 7).

Liberalizacja swobód obywatelskich, także w obszarze wolności wyznania oraz rejestracji związków wyznaniowych, może powodować w przyszłości, że Polska będzie stawać się powoli społeczeństwem zróżnicowanym wyznaniowo. W badaniach socjologicznych, zwłaszcza na próbach ogólnopolskich, te różnice nie są jeszcze statystycznie istotne i uchwytne. Niemniej ,,inaczej wierzący” są w ofensywie, stają się obiektem społecznego zainteresowania, także za sprawą mediów. Pomimo wzrostu zarejestrowanych wspólnot wyznaniowych liczebności ich członków nie są jeszcze statystycznie znaczące. W dającej się przewidzieć przyszłości odejścia od katolicyzmu do innych związków wyznaniowych nie będą masowe, pomimo bogatej i uzupełnianej oferty na rynku usług religijnych. Trajektorie przyszłości są trudne do precyzyjnego określenia, tym bardziej że we współczesnym świecie ujawniają się nie tylko silne tendencje sekularyzacyjne, pluralistyczne i indywidualizacyjne, ale i im przeciwstawne - kontrsekularyzacyjne, desekularyzacyjne i ewangelizacyjne.

Libiszowska-Żółtkowska nie podziela poglądu, że w najbliższych latach nastąpią jakieś radykalne przemiany w religijności społeczeństwa polskiego, przypuszcza, że będziemy mieć do czynienia zarówno z kontynuacją tradycji, jak i procesami przemian, polegającymi na modernizacji dziedzictwa, bądź na wyborze innej formy religijności. Przemiany w religijności Polaków zależeć będą od prestiżu Kościoła katolickiego jako instytucji, od oceny jego politycznego zaangażowania i charakteru społecznej posługi (Libiszowska-Żółtkowska, 1993, s. 94). Wydaje się ona podzielać pogląd, że w Polsce religijność jest ściśle związana z kościelnością (więź z Kościołem) i że osłabienie kościelności będzie rzutować na procesy identyfikacji religijnej (Mariański, Smyczek, 2011, s. 165-203).

W drugiej części zatytułowanej „Religijność w konfesyjnych, kulturowych i społecznych kontekstach” czytelnik otrzymuje następujące opracowania: Typy religijności w polskim społeczeństwie w początkach XXI wieku: trwałość i zmiana; Od religijności rodzinnej do duchowości indywidualnej - z biografii studentów; 
Uczeni o Kościele; Religia w trosce o zdrowie; Sens życia determinowany przekonaniami religijnymi; Fenomen pielgrzymek i pielgrzymowania. W kontekstach społeczno-kulturowych mających różne oblicza w poszczególnych regionach świata i w konkretnych krajach dokonują się przemiany w typach religijności. Religia jako forma „wielkiej narracji” podlega różnorodnym przemianom, które mają bezpośredni lub pośredni wpływ zarówno na życie jednostek, jak i społeczeństw. Poszczególne religie oraz systemy znaczeń konkurują i współzawodniczą ze sobą w interpretacji i wyjaśnianiu świata.

Z bogatej zawartości tej części pracy zwrócę uwagę tylko na typologię religijności w społeczeństwie polskim oraz koncepcję duchowości. Powszechnie przyjmuje się trójstopniową skalę w odniesieniu do populacji ludzi wierzących: głęboko wierzący, wierzący i powątpiewający (wątpiący, ambiwalentni). Głęboko wierzący na ogół deklarują swoją zgodność z religią zarówno w sferze dogmatów, jak i deklarowanych praktyk religijnych. Ich religijny światopogląd jest koherentny i wewnętrznie wspólny. Wśród wierzących socjologowie odnajdują brak spójności, wewnętrzne rozdarcia, wybiórczą akceptację prawd wiary oraz indywidualne interpretacje nakazów i zakazów Kościoła (religijność subiektywna, wybiórcza, selektywna, zindywidualizowana). W swoich wyborach moralnych nie zawsze kierują się wymaganiami Kościoła. Znaczący procent polskich katolików traktuje religię jako kulturową powinność, element więzi rodzinnej, odświętny i ceremonialny styl życia.

Trzeci typ katolików (wątpiący) nie został opisany szczegółowo, natomiast Libiszowska-Żółtkowska wskazuje na nowe nurty ideowe w katolicyzmie, związane z potrzebą osobistego przeżywania wiary i doświadczania duchowych emocji. Ludzie o nowych orientacjach przeżywają swoje fascynacje Transcendencją w samotnym skupieniu bądź poszukują ludzi podobnych sobie, by we wspólnocie dzielić się swoimi doznaniami. W obrębie Kościoła katolickiego lub na jego peryferiach powstają nowe ruchy religijne i wspólnoty kościelne (Libiszowska-Żółtkowska, 2004, s. 91-93). Ze względu na swoją dynamiczną działalność stanowią one już ważny segment religijnego pejzażu, a ich istnienie i rozwój powinny być impulsem do refleksji nad,,ofertą” Kościoła, która nie zawsze trafia do obszaru potrzeb religijnych zagospodarowanych przez sekty i nowe ruchy religijne o niekatolickim charakterze.

W polskiej religijności zakorzenionej w określonym kontekście kulturowym, historycznym i społecznym, Libiszowska-Żółtkowska wyróżnia już konkretnie cztery nurty: a) religijność ideowo propagowana przez ojca Tadeusza Rydzyka, dyrektora Radia Maryja; b) elitarna grupa inteligencji katolickiej, która podąża drogą wytyczoną przez ks. Józefa Tischnera; c) uczestnicy aktywnie działających ponad 
100 ruchów religijnych, które od wewnątrz zapobiegają erozji życia religijnego; d) katolicy niedzielni prezentujący typ religijności tradycyjnej, bezrefleksyjnej, niepogłębionej, kultywowanej bardziej z przyzwyczajenia niż z potrzeby serca (najliczniejsza populacja katolików) (Libiszowska-Żółtkowska, 2004, s. 94).

Socjologiczna typologia postaw wobec religii ujawnia zarówno ich wielość, jak i złożoność. Opisywane typy idealne czy modele religijności nie występują z reguły w postaci czystej, lecz w różnych połączeniach i konfiguracjach. Obserwuje się złożony proces ich interferencji. Tworzone typologie religijności mogą nie pokrywać się w pełni z rzeczywistością społeczną, ale dają syntetyczne przybliżenie do warunków w niej istniejących. Jedne z typologii są bardziej, inne mniej przydatne do wyjaśniania rzeczywistości społeczno-religijnej. Mają one znaczenie zarówno diagnostyczne, jak i wyjaśniające. Typologia religijności katolików polskich, zaproponowana przez prof. Libiszowską-Żółtkowską wymaga dalszych uściśleń teoretycznych i praktycznych, a przede wszystkich operacjonalizacji.

Maria Libiszowska-Żółtkowska należy do czołówki polskich socjologów religii zajmujących się problematyką duchowości, w tym i nowej duchowości. Posługuje się terminem „duchowość indywidualna”, które jest pojęciem szerszym niż „religijność”. Oznacza orientację na pozaludzkie moce, na sacrum, ale bez konfesyjnego zapośredniczenia (usytuowania). Chodzi tu o stopniowy proces oddalania się od wzorca religijności kościelnej (instytucjonalnej), ku indywidualnym wyborom wiary lub praktyk religijnych. Zaniechanie tradycyjnych form manifestacji wiary i kościelnych rytuałów nie jest równoznaczne z odejściem od sacrum. Ludzie współcześni nie tyle odchodzą od Boga, ile raczej poszukują go „na własną rękę”, odwołując się do wielu dostępnych im inspiracji („Bóg - tak, Kościół - nie”). Tak rozumiana duchowość jest przejawem religijności selektywnej lub religijności pozakościelnej. W badaniach socjologicznych zrealizowanych wśród studentów warszawskich tak rozumiana duchowość przejawiała się w postawach tych studentów, którzy odsunęli się od Kościoła, ale Bóg był w ich życiu jeszcze jakoś ważny (Libiszowska-Żółtkowska, 2010, s. 169).

W trzeciej części pt. „Nowe ruchy religijne i ich uczestnicy” zostały zamieszczone następujące teksty: Pluralizm wyznaniowy we współczesnej Polsce; Religijność konwertytów nowych ruchów religijnych; Tożsamość uczestników wspólnot religijnych; Homo religiosus - teoria wyjaśniająca kazus pastafarian; Kościół i religia publicznej przestrzeni miejskiej. Kazus Kościoła Ulicznego przykładem chrześcijańskiej służby etycznej; Granice tolerancji wobec religijnych inaczej.

Maria Libiszowska-Żółtkowska jest bez wątpienia klasykiem w polskiej socjologii nowych ruchów religijnych. Jej prace z tej dziedziny weszły na stałe do klasycznych osiągnięć polskiej socjologii religii. W swoich pracach charakteryzuje 
zjawisko nowych ruchów religijnych, ich genezę, podstawy doktrynalne i kultowe. W socjologicznej charakterystyce nowych ruchów religijnych ujmuje problem nie tylko od strony teoretycznej i semantycznej, ale i praktycznej, np. religia a zdrowie, mechanizmy i motywy wyboru nowej wiary, a także opisy wybranych grup religijnych. Stawia też ważne z empirycznego punktu widzenia pytania, dlaczego ludzie poszukują innych wierzeń religijnych niż te, które przekazali im w dzieciństwie rodzice. Próbuje też określić poziom przyzwolenia społecznego dla mniejszości religijnych.

Autorka dokonuje wielu niezwykle ważnych ustaleń definicyjnych w zakresie kluczowych pojęć odnoszących się do nowych ruchów religijnych, rozważa dylematy aksjologiczne doświadczane przez badaczy tej problematyki (z próbą rozwiązań optymalnych) oraz osadza własne propozycje badawcze w dokonaniach wcześniejszych, znanych z literatury obcojęzycznej. Dochodzi do wypracowania teoretycznego modelu badań nowych ruchów religijnych, który pozwala na wieloaspektowe i wielostronne ujęcie problemu, ujawnienie mechanizmów rozwoju i rozpowszechniania się nowych ruchów religijnych, osobowościowych i skutecznych skutków członkostwa w nowych wspólnotach oraz sposobów funkcjonowania samych ruchów i wspólnot religijnych (rekrutacja, zaspokajanie potrzeb, organizacja życia, wewnątrzgrupowego, uznawane i realizowane wartości, stosunek do społeczeństwa jako całości). Libiszowska-Żółtkowska zapoczątkowała w Polsce dwie nowe subdyscypliny: socjologię nowych ruchów religijnych i socjologię konwersji (Baniak, 2011, s. 135-163).

Przedstawiając i tym samym zapowiadając wybrane problemy zawarte w recenzowanej książce, wypada jeszcze dodać, że jej autorka w odniesieniu do zamieszczonych w niej tekstów, zawłaszcza tych z XXI wieku, dokonywała niekiedy określonych zabiegów zarówno o charakterze edytorskim (np. skracanie niektórych fragmentów), jak i merytorycznym (np. dopisywanie krótkich wątków), nienaruszających jednak istoty tekstów zamieszczonych w pierwotnych wydaniach. Całość opracowania zamyka bibliografia odnosząca się do wszystkich osiemnastu tekstów zawartych w książce „Homo religiosus”. W „Przedmowie” autorka pisze: „Z przyjemnością powróciłam do moich starych tekstów, które - wydaje się - nie straciły wiele na swej aktualności. Pozostawiam je takimi, jakie były, nie konfrontuję ich z dniem dzisiejszym, nie dopisałam uaktualnień, bo wtedy książka miałaby podwójną objętość. Frajdę porównania tego, jak było, z tym jak jest, pozostawiam czytelnikowi”. Wielu z nich przeżyje z pewnością tego rodzaju doświadczenie naukowe. 


\section{Bibliografia}

Baniak, J. (2011). Konwersja religijna i konwertyci polscy w badaniach religioznawczych i socjologicznych Pani Profesor Marii Libiszowskiej-Żółtkowskiej. W: J. Mariański, E. Stachowska (red.), Między religiq a religioznawstwem w teorii i badaniach Marii Libiszowskiej-Żółtkowskiej. Warszawa: Polskie Towarzystwo Religioznawcze.

Libiszowska-Żółtkowska, M. (1991). Postawy inteligencji wobec religii. Studium socjologiczne. Warszawa: Instytut Filozofii i Socjologii PAN.

Libiszowska-Żółtkowska, M. (1993). Religijność Polaków na przełomie wieków - stan aktualny i perspektywy. Przegląd Religioznawczy, 2.

Libiszowska-Żółtkowska, M. (1998). Religia w trosce o zdrowie. Wybrane zagadnienia z pogranicza socjologii medycyny i socjologii religii. W: M. Libiszowska-Żółtkowska, M. Ogryzko-Wiewiórowska, W. Piątkowski (red.), Szkice z socjologii medycyny. Lublin: Wydawnictwo UMCS.

Libiszowska-Żółtkowska, M. (2000). Wiara uczonych. Esej socjologiczny mocno osadzony w empirii. Kraków: Zakład Wydawniczy NOMOS.

Libiszowska-Żółtkowska, M. (2004). Typy religijności w społeczeństwie polskim w początkach XXI w. - trwałość i zmiana. W: J. Baniak (red.), Katolicyzm polski w warunkach Unii Europejskiej: szanse i zagrożenia, obawy i nadzieje. Poznań: Redakcja Wydawnictw UAM - Wydział Teologiczny.

Libiszowska-Żółtkowska, M. (2010). Od religijności rodzinnej do duchowości indywidualnej - z biografii studentów. W: M. Libliszowska-Żółtkowska, S. Grotowska (red.), Religijność i duchowość - dawne i nowe formy. Kraków: Zakład Wydawniczy NOMOS.

Mariański, J., Smyczek, L. (2011). Marii Libiszowskiej-Żółtkowskiej badania nad katolicyzmem polskim. W: J. Mariański, E. Stachowska (red.), Między religiq a religioznawstwem w teorii i badaniach Marii Libiszowskiej-Żółtkowskiej (s. 165-203). Warszawa: Polskie Towarzystwo Religioznawcze. 